Krzysztof Popiński (Wroctaw University of Economic and Business, Wrocław)

ORCID: 0000-0002-5594-7838

krzysztof.popinski@ue.wroc.pl

\title{
WROCLAW ELECTRONIC WORKS: WROCŁAWSKIE ZAKŁADY ELEKTRONICZNE „ELWRO” 1959-2000
}

\begin{abstract}
Based on the research potential of the Wrocław higher education center and its achievements in mathematics and automation, Wrocławskie Zakłady Elektroniczne "Elwro" was launched in the capital of Lower Silesia, in the late 1950s. Starting with the production of relatively simple electrotechnical devices, the company transformed in just a few years into a manufacturer of digital machines of its own design, "Odra". They have found wide application in science, administration, communication and industry - both in Poland and abroad, mainly in the Comecon member states. The 1970s were the period of the peak development of WZE "Elwro", in which apart from devices of its own design, computers belonging to the so-called Uniform System of Digital Electronic Machines of Comecon countries, were also being produced. The effects of the economic crisis of the 1980s abruptly reduced the orders for computers produced in "Elwro", and their development and production was slowed down by problems with obtaining materials that were scarce in the country and foreign currency for foreign purchases. The technological distance between the "Elwro" offer and the equipment manufactured in the leading countries of the West was growing. After the start of the system transformation in the country, the management of "Elwro" attempted to carry out radical organizational transformations and grant the company the status of a joint-stock company. However, they were held back for too long by both the lack of government support and the concerns of the works council. Meanwhile, deteriorating economic results forced the management of "Elwro" to reduce employment and sell more and more assets. Ultimately, in 1993, the plants were transformed into a sole-shareholder company of the State Treasury, and then sold to the German concern "Siemens". For the new owner, the only thing that mattered was the access to the Polish telecommunications market obtained in this way. He did not use the still existing human resources and production potential of "Elwro" and, shortly after the purchase, practically liquidated the company. In 2000, its remains were sold to the American telecommunications company "Teletec Holding", which changed the name of the company to "Teletec Polska" S.A.
\end{abstract}

Keywords: Poland, Wrocław, IT industry, computers

doi: 10.2478/sho-2021-0005 


\section{INTRODUCTION}

In 1959, Wrocławskie Zakłady Elektroniczne "Elwro" was established. Starting their activity from the production of relatively simple electronic devices, within a few years they became the leading domestic producer of computers, then called digital machines, and many types of accompanying devices. They quickly achieved the position of a tycoon within the Council for Mutual Economic Assistance (Comecon). The development of "Elwro" was possible thanks to cooperation with local universities, such as Wrocław University of Technology, Wrocław University and Wrocław University of Economics. Universities educated staff for the Wrocław IT industry tycoon and participated, according to their specialization, in scientific and research activities conditioning the technical and technological progress of "Elwro". The "Elwro" plant was the main supplier of equipment for the university's IT laboratories. They also supported university research projects in the field of computer science and its practical applications [Popiński K. 2017: 61-137].

The text has a chronological and problematic arrangement and covers the presentation of the conditions, stages, forms and scale as well as the importance of the operation of the Elwro plant. Its history was presented taking into account the changing political and socio-economic realities of Poland before and after 1989 and the main trends in the development of IT in Poland and in the world.

\section{THE CREATION AND THE FIRST DECADE OF DEVELOPMENT (1959-1970)}

The circumstances of the creation of "Elwro" and the commencement of the production of computers in the country are related to the decision made in March 1959 by the authorities of the People's Republic of Poland to accelerate industrialization again by increasing investments, primarily in the machine and chemical industry as well as the raw material and energy base. For the development of new industries, it was necessary to purchase Western technologies, which were to be financed from revenues from increased exports of fuels, raw materials and materials and thanks to the development of cooperation within Comecon. Priority was given to modern industries, including electronics and electrical engineering, capable of producing control and measuring equipment, digital machines 
and industrial automation, both for internal needs and for export. At the end of 1968, due to the slowdown in economic development and the modernization of the country, the plans were adjusted. Following the trends in the economy of the Western world and some more developed socialist countries, the concept of the so-called selective development was assumed. It put emphasis on the development of the most modern industries with high export potential, while reducing heavy and raw materials industries. Concentration, specialization and optimization of production within industrial plants was to introduce the Polish economy on the path of intensive development. Out of 55 industrial complexes planned for maintenance and development in the country, nearly $1 / 5$ were to belong to the electrotechnical and electronic sector. [Bałtowski M. 2009: 206-8; Morawski W. 2011: 273-81; Kaliński J. 2012: 40-3, 53-4].

Several factors determined the location of the center of the Polish computer industry in Wrocław. Certainly one of them was the potential of the local research center in the field of mathematics and automation, which made it possible to undertake pioneering work in Wrockaw related to the launch of production and design development of digital machines, and then the automation of technological systems as well as control and management systems. This premise did not have to prevail. However, aware of its strengths, the Wrocław scientific community, supported by the local Provincial Committee of the Polish United Workers' Party, undertook active efforts to obtain a favorable decision of the central authorities. They were also supported by the Social Committee for the Construction of the Wrocław Television Center established in 1957. With the support of several dozen Lower Silesian institutions and enterprises, it contributed to the construction of an installation on the nearby Ślęża mountain, enabling the reception of a TV program in the region. It also made efforts to open a TV factory in Wrocław. The implementation of this initiative was the beginning of the Wrocław computer tycoon. Wrocławskie Zakłady Elektroniczne "T21" was established by the decision of the Minister of Heavy Industry of February 6, 1959. Its name was later supplemented with the acronym "Elwro". Initially, the company started to produce channel switches and VHF heads for TV sets and electrotechnical products, devices for automatic regulation and control [Rutkiewicz I. 1966: 289-90; Maćkowiak B. et al. 2017: 15, 17].

The management and a team of designers of "Elwro" under the direction of Marian Tarnkowski - the first director of the company, however, wanted to start the production of digital machines from the very begin- 
ning. According to the plans from 1966 to 1970, the share of the latter in the total generated volume was to increase to at least $50 \%$. The digital machines produced at "Elwro" were to be used both for computational purposes and to use them to control technological processes. Based on the demand of individual ministries and preliminary export arrangements, a total of 321 machines were expected to be manufactured in the years 1965-1970, including 210 for domestic orders, and 111 for export. In 1964, the staff of WZE "Elwro" already included about 2,300 employees and over 50\% were women. The plans for the years 1966-1970 provided for an increase in the production value of the plant by as much as $300 \%$, and employment by over $200 \%$, compared to 1965 . Most of these plans were successfully implemented [APW, WZE "Elwro"... IV/1: 16, 120-2, 153; IV/2: 211-13, 225-7; Maćkowiak B. et al. 2017: 96-7].

The engineering team from "Elwro" trained in Warsaw scientific institutions created the Construction Office, initially headed by prof. Jerzy Bromirski. The engineers employed there conducted research on their own designs. In December 1960, the project of the digital machine "Odra 1001" was completed. The representatives of "Elwro" knew how to adapt to the political and ideological conditions of the time. The name of the machine, which gave rise to the entire family of computers manufactured in Wrocław, referred to the largest of the Silesian rivers and was at the same time dedicated to the celebration of the "Millennium of the Polish State" forced by the party and state authorities. The first model of the "Odra" was not yet suitable for mass production, but the experience gathered with it became the basis for obtaining consent to the continuation of work on digital machines in Wrocław. Professors Jerzy Bromirski from the Wrocław University of Technology and Jerzy Słupecki from the University of Wrocław participated in the design work on them. While the machines manufactured at the same time in the Warsaw center were still based on tube circuits, in the next model, "Odra-1002", which was created in 1961, predominantly domestic-made transistors were used. However, since the Ministry of Heavy Industry decided that this model is still not fully suitable for production, the decision to choose WZE "Elwro" as the main national center for the production of digital machines was accompanied by the decision that in the meantime "UMC-1" would be produced there. It was already a technologically outdated machine at that time, but it was proven. In the years 1962-1964, a total of 25 UMC-1 machines were produced in Wrocław under the supervision of Eugeniusz Bilski. They went into normal operation in the country, and one was even exported to 
Hungary [Zuber, R (nd); Miś B. 1974: 73; Kubiński G. 1999: 8-9; Madey J., Sysło M. 2000; Kluska B. 2013: 40-7; E-maile z USA... 2014: 47-8; Bilski E. et al. 2017: 13, 19-20; Hołyński M. 2019: 45, 48].

Despite the commencement of production of machines by Warsaw constructors, research works were not abandoned at the WZE "Elwro". In 1964, the plants then managed by Stefan Rylski managed to obtain the consent of the Ministry to start the production of the second generation machine "Odra 1003", developed by a team led by Eng. Thanasis Kamburelis. Its production lasted until 1965. 42 copies were made, several of which were exported to the USSR, Czechoslovakia and Hungary. The possibilities of the machine allowed, for example, to use it to control technological processes. It went to many institutions, universities and a number of leading production plants in the country. The Wrocław computer was five times faster than the "UMC-1". It performed 500 operations in a second. It also had a twice as large memory of 8,000 words. Moreover, it consumed ten times less electricity, weighed three times less and occupied twice less space [Miś B. 1974: 72-3; Kubiński G. 1999: 7-8; Maćkowiak B. et al. 2017: $18,20]$.

In 1966, "Elwro" started the production of the "Odra 1013" digital machine with a speed of 1000 operations per second, I.e. twice as fast as the previous model, with, apart from the internal drum memory, fast operating memory based on ferrite cores. The possibilities of "Odra 1013" were, in practice, still limited to narrow and specialized groups of issues, such as materials management, preparation of payrolls, organization of transport. In the years 1966-1967 a total of 84 copies of this machine were produced, 49 of which were exported. The team of designers of the "Odra 10011013" series of machines was headed by Jan Markowski [Chełchowski J. 1969: 141; Tempski Z. 1970: 198-9; Elwro. Zakłady Elektroniczne... 2000; Maćkowiak B. et al. 2017: 18, 20-2; Hołyński M. 2019: 58].

In 1967, the "Odra 1103" computer, designed by a team of designers led by Jura Lesiński and Piotr Kociatkiewicz, was put into production. In order to speed up the work and minimize the technical risk, its mechanics and electronics were based on the solutions used on the already manufactured computer "Odra 1013". However, its architecture and logical structure were created from scratch. Its ferrite working memory had a capacity of 1024 words, four times more than its predecessor. New software was developed for "Odra 1103" along with utility applications useful for running payrolls in enterprises or material and warehouse management. In the years 1968-1969, a total of 64 copies of this machine were produced, 
of which 8 were exported to Czechoslovakia [Lesiński J., Kociatkiewicz P. 2017: 277-9].

In 1967, under the supervision of T. Kamburelis, work was completed on another digital machine -“Odra 1204". It was the first microprogrammed machine in Poland, i.e. its logical structure was stored in a module called permanent memory. This allowed for a significant reduction in its central unit and led to a reduction in the cost of construction and an increase in its reliability. It was already a fully second generation digital machine, and therefore based on transistors, with three types of memory: ferrite, tape and drum. The machine ran at 50,000 operations per second, the capacity of the ferrite memory was increased to 16,000 words, and the capacity of the drum memory was increased to 130,000 words. As the first Polish digital machine, it could perform two tasks simultaneously and signal errors made when entering a program into it. Its rich and modern software was developed by employees of WZE "Elwro" and mathematicians from the University of Wrocław. Until 1972, 179 copies were produced, 114 of which were exported to the USSR, Czechoslovakia, Hungary and the GDR. The machine was used, among others to control the first numerical machine tools. Due to the development of export production, "Elwro" became one of the four companies in Poland that obtained the authorization to operate independently in foreign trade without the mediation of the Foreign Trade Center [Miś B. 1974: 73; Elwro. Zakłady Elektroniczne... 2000; Kubiński G. 1999: 8-9; E-mails from the USA... 2014: 47-8; Zuber R. (nd); Bilski E. et al.2017: 14].

Another qualitative leap was made in the same year 1967 when the Wrocław plant started cooperation with the British company "ICL". It was an implementation of the idea of constructing a computer in Poland that would accept more developed Western basic and utility software. Under the agreement, "Elwro", by purchasing two large computers, "ICL 1904", simultaneously obtained their logical documentation and tapes with full basic and utility software. Thanks to the contract, the internships of Wroclaw designers and programmers began at the "ICL" plants, which were continued until the early 1980s and played an important role in improving the qualifications of "Elwro" employees [Kulisiewicz T. 2017: 67-8; Bilski E. et al. 2017: 14-7; Hołyński M. 2019: 59-61].

Thanks to the documentation provided by "ICL", T. Kamburelis' team completed "Odra 1304" in 1970. It used technical solutions from "Odra 1204 ". A total of 90 copies of this machine were built, 17 of which were exported. Thanks to the rich and proven software, "Odra 1304" was the 
first Polish 3rd generation digital machine built with the use of integrated circuits that could be used for data processing. Its modular layout made it possible to put together any configuration depending on the needs. "Odra 1304" computers constituted the basis of data processing systems in "ZETO" computing centers and operating at mining and energy industry enterprises, railways, construction, as well as in banking and statistical institutions [Zuber R. (nd); Kluska B. 2013: 47-52, 54-8; Kamburelis T., Piwowar B. 2017: 18-9; Kulisiewcz T. 2017: 68; Maćkowiak B. et al. 2017: 23-5; Hołyński M. 2019: 61].

And yet, there are also opinions that the strategy adopted by "Elwro", although it allowed for a significant technological leap forward, at the same time, in the long run, brought serious negative consequences. In order to be able to use the purchased software, the computers produced by Elwro had to essentially duplicate the English specification from 1960, inevitably becoming more and more obsolete. It seems, however, that the general reason for the insufficient use of the acquired licenses was the systemic inability of the command-and-control economy to develop modern technologies. In all Comecon countries, software development was included in the production the value of which was based on the so-called material charge. And this in the case of software was almost zero. Therefore, it was not profitable for IT equipment manufacturers, such as "Elwro", to produce it, because from the point of view of the overall settlement of the enterprise, it created unnecessary costs [Kulisiewicz T. 2017: 88; Ziemkiewicz A., Jezierska-Ziemkiewicz E. 2017: 112-3; Hołyński M. 2019: 63-4].

Meanwhile, nevertheless, the successes of WZE "Elwro" in introducing new models of "Odra" machines into production seemed unquestionable. In the late 1960s, however, the concept of making a technological and organizational leap in the IT industry was born in the USSR. In February 1968, under pressure from the Soviet authorities, the Comecon countries agreed to base their IT systems on a compatible series of machines, the socalled Uniform System of Electronic Digital Machines (RIAD). As part of the division of labor, the Polish side was granted the production of medium-sized machines marked with the symbol "R-30". The development of own digital machines was put into question in Elwro and in Poland in general [G. Kubiński G. 1999: 3-4; Kluska B. 2013: 53-4; Kulisiewicz T. 2017: 89-90]. 


\section{IN TIMES OF ACCELERATED DEVELOPMENT (1970-1980)}

Changes at the top of the authorities in December 1970 resulted in a revision of the socio-economic program. The selective development model has been replaced by the concept of acceleration and sustainability. It assumed that economic growth would be accompanied by simultaneously satisfying social needs in terms of consumption. The transition to intensive economic development was to be achieved through concentration and specialization of production. Comprehensive investment projects were planned in the machinery, metallurgical, chemical and light industries, as well as in the electronics and electrotechnical industries. The achievement of this goal was facilitated by the favorable international situation in the 1970s, shaped by the détente in relations between the East and the West. This facilitated access to Western loans and enabled the purchase of modern licenses and machines. Investments on credit brought significant economic growth in the first half of the 1970s. However, the rise in prices following the oil crisis in the second half of the decade increased the cost of servicing foreign loans, especially those incurred in capitalist countries. Although exports grew and its structure improved in favor of the electromechanical industry, it was directed mainly to socialist countries. The technologically backward products of the Polish industry did not gain enough sales in the West to be able to balance the growing debt. At the same time, the investment boom took place in the then Poland without carrying out deeper structural reforms of the socialist economy and without improving the efficiency of enterprises. The central authorities lost control over the economy in favor of powerful unions, such as the "Mera" Union, to which, from 1964, Wrocław's "Elwro" plant belonged. In the absence of competition and threats of bankruptcy, they raised prices with impunity, carried out uncontrolled investments, fought with each other for scarce materials and foreign exchange funds, did not take into account production costs and product quality [Bałtowski M. 2009: 210, 222-30, 235-41; Kaliński J. 2012: 43-5; Hołyński M. 2019: 69-70].

One of the beneficiaries of the influx of modern techniques and technologies to the country was the computer manufacturer from Wrocław. Pursuant to the decision of the 6th Congress of the Polish United Workers' Party in December 1971, "Elwro" was entrusted with a number of strategic functions in the years 1971-72. It was to produce and maintain the Unified System computers and conduct their technical maintenance 
as well as perform the function of the General IT Equipment Supplier. Thanks to the granted powers, the Elwro plant played a leading role in the Mera Union. In the 1970s, the annual production of computers fluctuated around 100 units per year. In order to ensure proper servicing of the digital machines produced by it, a network of "Elwro-Serwis" branches was established in the country, and a network of Technical Service Points in Moscow, Prague, East Berlin, Budapest, Kiev, Bratislava and Pardubice was established abroad. The basis of production was to be computers, among which "R-32" were to account for $50 \%$ by 1980 , which was achieved due to the gradual phasing out of the production of "Odra" machines. The management of "Elwro" planned, in the 1970s, to increase production several times compared to the beginning of the decade. In total, it was to supposed to produce, by 1980, over 5,000. computer sets, of which up to $20 \%$ was to be exported. The implementation of these plans was made dependent on the increase in production capacity based on a special investment loan and close cooperation with the "Mera" Union, whose companies were to increase production for the needs of "Elwro", as well as increase the import of necessary components, materials and software elements. Ultimately, these intentions turned out to be largely unrealistic, especially when it comes to computers. During the entire decade, only a few hundred were produced, not several thousand as planned. In the production structure, the importance of calculators, such as the "Elwro $105-\mathrm{LN}^{\prime \prime}$ produced in tens of thousands of pieces per year in cooperation with the Japanese company "Busicom", was growing, as well as own designs for personal and office use and various components sold separately, such as memory drum PB-204-2 sold mainly for the company "Robotron" from the GDR [APW, WZE "Elwro"... IV/15: 8-11, V/13: 1, V/14: 15-7; Maćkowiak B. et al. 2017: 30-3, 44-7].

The specificity of "Elwro" was behind the high share of highly qualified staff with higher and secondary education among its employees. In 1975, WZE “Elwro" employed 5,500 people, including 10\% with higher education, and $31 \%$ with secondary education. Every year, about 500 employees underwent various forms of improving qualifications, from extramural and postgraduate studies, courses, etc. organized in cooperation with universities $[A P W$, WZE "Elwro"... V/13: 1-16, 21-5, 30-4; IV/14: 3-8, 15-7, 24-5, 30-2; V/15:. 5-8].

The successors of the "Odra 1304" were, from 1972, the "Odra 1305" and "Odra 1325" models. Adam Urbanek was the main constructor of the central unit of the "Odra 1305" computer. In total, by 1983, 587 machines 
from the "Odra 1300" series were produced, a significant part of which was exported to the Comecon countries, mainly the USSR. They were the first 3rd generation machines prepared in Poland based on advanced versions of integrated circuits. "Odra 1305" performed 150 thousand operations per second, had operational memory with a capacity of 1 million characters and external memory with a capacity of 100 million characters with the possibility of extension. Its computing power and performance were comparable to the IBM S / 370-145 and 155 computers. It worked in the time division, had a modular structure, adapted to work in multi-access and multi-machine systems. In turn, "Odra 1325", created under the leadership of Zbigniew Wojnarowicz, worked at a speed of 200,000 operations per second, and its working memory could be expanded to about 4,000 characters. "Odra 1325" was a multi-program, multi-processor, multi-access machine working in real time, and its software was compatible and interchangeable with earlier models. The career of machines from the "Odra 1300" series was possible due to good performance, rich software, and a whole set of external devices - printers, drawing devices, tape memories, readers and perforators. In the country, they were used in activities aimed at computerization of the economy, including construction and railways, as well as institutions such as the Central Statistical Office or universities. They educated a whole generation of Polish IT specialists. Using the technology of "Odra 1305", the Faculty of Military Technology "Elwro" in cooperation with Pardubice "Tesla" constructed a series of computers for the needs of air defense systems in Poland, Czechoslovakia and other countries of the Warsaw Pact. They were also used to build the first multi-access subscriber system in Comecon - a joint work of IT specialists from Wrocław University of Technology and "Elwro" engineers [E-mails from the USA... 2014: 47-8; Wspomnienia... (nd); Kubiński G. 1999: 10-1; Bilski E. et al. 2017: 19-21; Maćkowiak B. et al. 2018: 36-9; Hołyński M. 2019: 61-2].

At the end of 1971, WZE "Elwro" was given a completely new task, which was to significantly change the company's own plans, limiting the development of its own designs of the "Odra 1300" series. In November 1971, pursuant to the decision of the Ministry of Heavy Industry, the plants took over all matters related to the production of the "R-30" computer. Their starting structure and software were based on the first representative of 3rd generation computers, illegally copied by the USSR, "IBM 360". However, tests of the prototype created in 1972 showed that the "R-30" is an unreliable machine. At that time, at the discreet order of the manage- 
Table: Production of selected types of computers in Elwro 1962-1991

\begin{tabular}{|c|c|c|c|}
\hline Model & $\begin{array}{c}\text { Years } \\
\text { of production }\end{array}$ & $\begin{array}{c}\text { Production in } \\
\text { number of items }\end{array}$ & $\begin{array}{c}\text { Export in number } \\
\text { of items }\end{array}$ \\
\hline UMC-1 & 1962-1964 & 25 & 1 \\
\hline Odra 1003 & 1964-1965 & 42 & 10 \\
\hline Odra 1013 & 1966-1967 & 84 & 49 \\
\hline Odra 1103 & 1967-1969 & 64 & 8 \\
\hline (military) & 1967-1969 & 50 & 2 \\
\hline Odra 1204 & 1968-1972 & 179 & 114 \\
\hline Odra 1304 & 1969-1973 & 90 & 17 \\
\hline Odra 1305 & $1972-1983$ & 432 & 48 \\
\hline Odra 1325 & $1972-1983$ & 151 & 24 \\
\hline "R-32” & 1973-1986 & 175 & 15 \\
\hline "R-34” & $1987-1991$ & 106 & 34 \\
\hline RODAN-10 (military) & 1974-1986 & 186 & 80 (about) \\
\hline RODAN-15 (military) & 1986-1991 & 35 & 35 \\
\hline (military) & 1981-1988 & 46 & 0 \\
\hline
\end{tabular}

Sources: Author's work based on: Bilski E. et al.[ 2017: 20]; Maćkowiak B. et al. [2017: 96-7]; Kulisiewicz T., [2017: 70].

ment of "Elwro", based on newer technologies used in the production of machines from the "Odra 1300" series, the team led by Bogdan Kasierski significantly modified the Soviet design. The model, named "R-32", programmatically compatible with other machines of the Unified System, was put into production in 1973. Its technical parameters were significantly better than both the Soviet prototype and all other "RIAD" machines of its category produced by Comecon, in comparison to which it was much smaller and faster and less unreliable. It performed over 200,000 operations per second. At the IT fair in Brno, a comparison was made of the time taken by "RIADs" produced in different countries to perform 1 million operations. While the "R-20" produced in Minsk and Bulgaria needed 200 seconds, the "R-30" from Yerevan - 70 seconds, the Wroclaw "R-32" only 7 seconds. Although at a similar time, because in 9 seconds, the "R-40" from the GDR did it. But it was a machine five times larger. A total of 175 "R-32" machines were built, 15 of which were exported to Comecon countries, mainly to Czechoslovakia and Hungary, and 2 copies 
went even to Great Britain. The introduction of "R-32" into production in the years 1974-75 meant a gradual reduction in the export of "Odra" machines [Kluska B. 2013: 79-87; Kulisiewicz T. 2017: 83-4; Maćkowiak B. et al. 2018: 39-41; Hołyński M. 2019: 94-9].

On March 5, 1976, WZE "Elwro" transformed into the Center of Computer Systems for Automation and Measurements "Mera-Elwro". The production range expanded to include electronic automation and control and measurement equipment for the analysis of physical and chemical parameters used in environmental protection, and later also water quality monitors, gas chromatographs, teleprocessing systems and mobile laboratories. The "AW-11" laboratories based on the "Nysa" delivery vehicle and the N132 caravan turned out to be a real export hit of "Elwro". Over a thousand of them were sold to the countries of Eastern Europe, mainly the USSR. The electronic automation produced in "Elwro" was used to automate technological processes in various industries, especially in the power industry and metallurgy [Maćkowiak B. et al. 2018: 27, 42-3].

\section{IN THE YEARS OF CRISIS (1980-1989)}

The socio-economic and political crisis in Poland, which had been growing since the second half of the 1970s, reached its full scale in the 1980s. The beginning of this decade brought a breakdown in Polish foreign trade. The situation was aggravated by the restrictions of Western states after the introduction of martial law. Imports from socialist countries could not replace purchases in the West, as the shortage of goods needed by Poland affected the entire Eastern Bloc, and the Polish economy, especially industry, became dependent in the 1970s on the import of Western technologies. It was not until the mid-1980s that relations with the West gradually improved and cooperation was renewed. In the 1980s, the position of the USSR in the geographic structure of Polish trade was strengthened due to credit assistance and the possibility of barter of goods. The USSR received $62 \%$ of exports of industrial products, including electronic. In exports, the importance of raw materials and low-processed products increased, and the importance of more complex industrial products, with the exception of electronic devices and computers, decreased. The latter, built on the basis of components imported from the USSR and the West, were partly exported, especially to Comecon countries, supporting the repayment of foreign debt [Kaliński J. 2012: 82-3]. 
In mid-1981, the new director of "Mera-Elwro", Andrzej Musielak, introduced changes transforming the enterprise into a decentralized organization of eight subject-specific plants with a high degree of independence, operating according to the principles of full internal economic settlement. Meanwhile, the external conditions for the functioning of "Mera-Elwro" became more and more difficult. After the introduction of martial law in Poland on December 13, 1981, the plants were temporarily militarized. Economic restrictions introduced by the West against Poland led to the termination of contracts for the import of electronic components and scarce materials used in the production of own products. This had a negative impact on development works and current production. The technological delay increased. The economic crisis in the country also severely limited orders from enterprises and institutions for computers of the "Mera-Elwro" plant. On October 28, 1982, by order of the Minister of Metallurgy and Machine Industry, the name of the company was changed to Zakłady Elektroniczne "Elwro" [Maćkowiak B. et al. 2017: 48].

Meanwhile, in Western countries, since 1980, PCs have rapidly spread. Thanks to the rich software and high quality and convenience of use at a relatively low price, they conquered the market of home and office computers in an avalanche. Their creator was the American "IBM", but quickly the production of kits compatible with the PC and the MS-DOS operating system was also undertaken by many other companies in the world. Unfortunately, at that time the Polish computer industry, including the "Elwro" plants, was still at the stage of producing narrowly specialized digital machines for large enterprises and institutions, based on technologies from the turn of the 1960s and 1970s. At the end of 1986, "Elwro" essentially ended production of "Odra" computers of the "1300" series. The production of the "R-32" also ended in the same year. The main product of "Elwro" was to become another Unified System computer, "R-34", with higher processing efficiency and operating memory. However, it was already outdated, unreliable and expensive to use at the time of launching production. Although the administration and national economy plants, which had great problems with obtaining deficit in exchangeable currencies in Poland, were condemned to computers manufactured in the country anyway, they were purchased in less and less quantity. Ultimately, 106 units were produced by 1991, of which 34 were exported [Kluska B. 2013: 91-106, 187-8, 197-8; Popiński K., 2017: 105; Maćkowiak B. et al., 2017: 51-4]. 
In 1983, "Elwro" started the production of "Elwro-500" microcomputers, based on a copy of the Intel 8080 microprocessor. This model, like its slightly smaller successor, "Elwro-600", was produced in the amount of only a few hundred pieces per year, much smaller than originally assumed. It did not develop on a larger scale, both due to supply problems, too high taxes, and in the second half of the decade also due to competition from massively imported microcomputers from abroad. It seemed that the chance for the development of the WZE "Elwro" plants appeared in 1986, when the Ministry of Education announced the universal education program in the field of IT knowledge. As part of it, it was intended to provide Polish schools with 75,000 microcomputers within a few years. The set design developed by a team of designers from Poznań was selected in a competition, and its production, which began in 1987, was entrusted to the Wrocław tycoon. However, the production of the "Elwro-800 Junior" computer was problematic. It was also too difficult to use for young people and teachers, in addition to being an emergency and lacking the necessary application software. Until the end of the 1980s, only a few thousand pieces were produced. Their production ended at the beginning of 1990, when the Ministry of National Education decided to adopt the "IBM PC" standard for school computers. As early as 1988, "Elwro" started the production of professional microcomputers "Elwro-801", the first Polish PC / AT computers equipped with "Microsoft" software, intended for state offices, companies and institutions. It turned out, however, that in the conditions of increasing competition from import, it was not possible to develop it on a larger scale [Sysło M. 1994: 3; Elwro. Zakłady Elektroniczne „Elwro"... 2000: 174; Kluska B. 2013: 103-8, 136-60, 174-86].

In the1980s, the assortment structure of production in "Elwro" changed. The share of large computers and external devices decreased, while the production and sale of new products, including microcomputers, teleprocessing processors, mobile laboratories and industrial automation systems, increased. In 1989, Elwro products were exported to 16 countries in Eastern and Central Europe, Western Europe, Cuba, China, India, Turkey and Iraq. When the provisions of the Commercial Code were restored in Poland at the beginning of 1988, "Elwro" took steps to link the enterprise with other entities in the form of capital companies. In the years 19881990, 15 companies were affiliated or established with the participation of Elwro, including two with foreign participation. In terms of the development and production of hardware, software, IT systems, power supply and automation, 6 of them were active: "Advacom" in Poznań, "Imcon" 
in Gliwice, "Mercomp" in Warsaw, "Promin" in Bydgoszcz, "Mera" in Warsaw and "Amatest" in Tbilisi (it was not finally registered in the USSR). The distribution of "Elwro" products for industrial plants, banks, accounting and schools in the country was handled by: "Elwro-System", "Elba" and "Eliks" from Wrocław and "Nauka" in Warsaw. In turn, the companies "Cenzin" (military computers), "Budimex Eko" in Warsaw (systems and equipment for environmental protection) and "Elwro-45" in Wrocław (Polish-French company - implementation of application programs in France) and "Set-Superwave Trading" in West Berlin, supported export activities. At the end of 1990, the total amount of "Elwro" shares contributed in these companies, only in cash, was PLN 245.4 million. In addition, they joined the "Employee Ownership Bank" (Bank Własności Pracowniczej) in Gdańsk, whose task was to support the employees of "Elwro" during the process of ownership transformation of the plants. Efforts to establish another company were also advanced - in Budapest, which was to deal with distribution and service [Maćkowiak B. et al. 2017: 49-51, 58-60].

\section{TRANSFORMATIONS AND COLLAPSE (1989-2000)}

In 1989, the transformation process into a market economy began in Poland. The internal convertibility of the zloty was implemented, inflation was suppressed, the budget balance was restored, prices were freed, subsidies for enterprises were abolished, foreign trade and labor law were liberalized, interest rates were made real. At the same time, however, there were also problems such as a decrease in the incomes of the population and economic entities, a decrease in GDP and production. This led to the collapse of many state-owned enterprises and unemployment. The losses suffered by the industry resulted not only from the actions taken during the transformation period, but also from its defective structure inherited from the period of socialist industrialization and from the breakdown of cooperation with the Comecon countries. More than $40 \%$ of the plants built in the times of the Polish People's Republic collapsed. Among the affected industries, the electrotechnical industry was among these hit hardest. After 1991, industrial production, under the influence of favorable organizational and structural changes, better adapted to the requirements of international competitiveness, re-entered the path of gradual growth. An important element of the changes was the privatization of state-owned en- 
terprises. The largest and most prosperous ones, after being transformed into one-person companies of the State Treasury, were offered to foreign investors. During the negotiations, attention was paid to both the confirmation of the investment commitment and the protection of employee interests. Small and medium-sized enterprises, as well as those in a difficult financial situation, were privatized through liquidation. Their property was sold, brought into companies or given for use to employee companies for remuneration. The pace of privatization depended on the political will of successive governments and was variable. The sale of industrial property as part of capital privatization has become an important source of state income.

In January 1991, the new director of "Elwro", Władysław Kierzkowski, presented proposals for radical changes in the organization and scope of operations of the plants, which were approved by the Delegates Meeting and the Workers' Council. However, it was too late for effective changes. In 1991, a significant drop in orders for Elwro products was already visible. At the end of this year, "Elwro" still employed 2,133 people. However, the financial result was already negative. The increasingly limited activity of the company at that time concerned only the processing of plastics and sheet metal, the production of printed circuits, cables, electronic components, the production of calculators, as well as tools and devices. Problems with selling products manufactured by "Elwro" deepened in the following year. There were even cuts in telephone services for the company due to unpaid bills. More customers were lost. Trials for collective redundancies of employees were started, for which the consent of the trade unions was obtained. "Elwro" found itself on a downward slope, heading for collapse. At the end of 1992, foreign and domestic trade and service centers of the plants were closed. The process of selling the company's facilities and equipment was progressing. Its financial situation deteriorated dramatically. Elwro lost its ability to pay and was unable to service its current debt [Maćkowiak B. et al. 2017: 73-5, 98-9].

After partial debt relief on August 23, 1993, the state-owned company Zakłady Elektroniczne "Elwro" was transformed into a sole-shareholder company of the State Treasury with a capital of PLN 20 billion. A month later, the State Treasury sold $80 \%$ of the shares of the German company to "Siemens" A.G. This transaction gave "Siemens" a license to sell telecommunications exchanges on the Polish market. By becoming the owner of "Elwro", "Siemens" did not attempt to use its human resources or pro- 
duction potential. Within a few months, $65 \%$ of the staff were dismissed, offering employees very high severance pay. In the years 1996-1999 the company's activity was limited to the production of precision details and components made of thermoplastics and sheet metal, lighting ballast tools, electronic components and computer equipment regeneration services for domestic and foreign customers. Employment fell from 194 people in 1996 to 173 at the end of 1999. On February 29, 2000 "Siemens" A.G. sold "Elwro" S.A. to the American telecommunications company "Teletec Holding" Inc. The Americans declared their willingness to implement advanced ICT technologies in Poland, and also that "Elwro" would constitute a European production bridgehead for their expansion. However, nothing of the sort happened in the following years. The new owner changed the name of the company from Zakłady Elektroniczne "Elwro" S.A. into "Teletec Polska" S.A., which symbolically ended their history [Maćkowiak B. et al. 2017: 80-1, 99].

\section{SUMMARY}

Wrocławskie Zakłady Elektroniczne "Elwro" stood out among enterprises operating in the realities of the People's Republic of Poland by having exceptionally modern specialization, effective cooperation with the research and development sector and high dynamics of activities carried out in the country and abroad. The career and collapse of "Elwro" were related to the general conditions of the economic system in the times of the Polish People's Republic and the beginning of the transformation to a market economy after 1989. Thanks to the enthusiasm and professionalism of the staff, efficient management at that time, Elwro managed to expand, on an international scale in the 60s and 70s, the design and production of digital machines and associated devices, educate multitudes of specialists to operate them and implement numerous applications of IT technologies. However, this did not prevent the company from gradually degrading and ultimately collapsing after a period of successful operation. However, the responsibility for this should not be blamed on the management or the staff of the plants, but above all on the systemic inability of the People's Republic of Poland to effectively apply and use innovations in any sphere of its operation. The system at that time discouraged company management from using new technologies. The low level of the national scientific and technical potential and its limited participation in international coop- 
eration led to the widening of the technological gap between the Polish industry and highly developed countries. The economic crisis in Poland in the 1980s reduced orders for the company's products on the domestic market. The political consequences of the imposition of martial law limited the availability of Western technologies. At the turn of the 1980s and 1990s, the general political and economic changes in the world hurt "Elwro". The break-up of the community of socialist countries disintegrated the existing economic ties and led to the loss of Elwro's foreign markets, which were important to it. The systemic transformation of the Polish economy after 1989 did not open up new development paths for the Wrocław plant. Successive governments saw no need to pursue an active industrial policy, or to maintain and develop strategic industries and entities of the Polish economy. The delayed transformation of "Elwro" into a joint stock company of the State Treasury, and then sale of the company to a foreign investor without any real guarantees for maintaining its production potential, determined the fate of the plant. Legal regulations, which gave too much power over the fate of industrial plants to poorly prepared workers councils, also played a role in the fall of "Elwro". The remaining legend of "Elwro" and "Odra" computers, proof that Polish engineers or managers, under favorable conditions, and sometimes against them, are able to join the mainstream trends in global scientific, technical and economic progress.

\section{REFERENCES}

\section{Archives sources}

APW - Archiwum Państwowe we Wrocławiu

WZE „Elwro" - Wrocławskie Zakłady Elektroniczne „Elwro”

APW, WZE "Elwro", Dział Planowania i Statystyki - Plany pięcioletnie produkcji 19661970, sygn. IV/1.

APW, WZE „Elwro", Dział Planowania i Statystyki - Plany pięcioletnie produkcji 19661970 , sygn. IV/2.

$A P W, W Z E$ „Elwro", Dział Poligrafii, Działalność gospodarcza przedsiębiorstwa w latach 1971 - 72 / materiały na konferencję sprawozdawczo - wyborczą KZ PZPR/, Wrocław, grudzień 1972, mszp., sygn. V/13.

APW, WZE „Elwro”, Osiągnięcia WZE „Mera-Elwro” między VI a VII Zjazdem PZPR. Kierunki działalności przedsiębiorstwa (materiały na konferencję partyjno-gospodarczą), grudzień 1975, sygn. V/14.

$A P W, W Z E$ „Elwro", Asortyment produkcji WZE „Elwro” i zasady specjalizacji w zakresie wytwarzania urządzeń informatyki w ZPAiAP, w: Prognoza produkcji WZE Elwro na lata 1976-1980, Wrocław, wrzesień 1972, 17.10.1972 r., sygn. IV/15. 


\section{Literature}

Bałtowski M. (2009), Gospodarka socjalistyczna w Polsce. Geneza - Rozwój - Upadek, PWN, Warszawa.

Bilski E., Huzar Z. (1999), Historia informatykiw Politechnice Wrocławskiej, Wydziałowy Zakład Informatyki, Wydział Informatyki i Zarządzania, Politechnika Wrocławska, Wrocław, pti.wroc.pl/html/.../historiaInformatyki/HISTORIA_Inf_PWr_EBilskiZHuzar1999. pdf, accessed 27.10.2020.

Bilski E., Kamburelis T., Piwowar B. (2017), Wrocławskie Zakłady Elektroniczne. Okres komputerów Odra 1300 [in:] Noga M., Nowak J.S. (eds.), Polska Informatyka: wizje i trudne poczatki, Polskie Towarzystwo Informatyczne, Warszawa, 11-35.

Chełchowski J. (1969), Przemyst elektroniczny, [w:] Baworowski J. (ed.), Przemyst Dolnego Śląska, PWN, Warszawa-Wrocław.

Dwilewicz Ł. (2017), Przemiany w polskim przemyśle 1989-2015 [in:] Problemy gospodarcze trzeciej Rzeczypospolitej, Oficyna Wydawnicza Szkoły Głównej Handlowej, Warszawa, s. 105-132.

Elwro. Zakłady Elektroniczne „Elwro” SA (2000), [in:] Encyklopedia Wroctawia, Wydawnictwo Dolnośląskie, Wrocław, 174.

E-maile z USA jechaty pociąiem... mówi dr inż. Józef Janyszek, zastępca dyrektora Wroctawskiego Centrum Sieciowo-Komputerowego, w rozmowie z Łukaszem Medeksza (2014), Pamięć i Przyszłość, 26, 44-53.

Hołyński M. (2019), Polska informatyka: Zarys historii, Polskie Towarzystwo Informatyczne, Warszawa.

Kaliński J. (2012), Gospodarka w PRL, Polskie Wydawnictwo Ekonomiczne, Warszawa.

Kaliński J. (2017), Przeksztatcenia własnościowe [in:] Jarosz-Nojszewska A. (ed.), Problemy gospodarcze trzeciej Rzeczypospolitej, Oficyna Wydawnicza Szkoły Głównej Handlowej, Warszawa, 91-104.

Kluska B. (2013), Automaty licza. Komputery PRL, Novae Res, Gdynia.

Kubiński G. (1999), Historia informatyki w Polsce (czasy PRL i początki transformacji), https:/ / depot.ceon.pl/handle/123456789/5823, accessed 27.10.2020.

Kulisiewicz T. (2017), Wtasne konstrukcje, licencje, klony [in:] Noga M., Nowak J.S. (eds.), Polska Informatyka: wizje i trudne początki, Polskie Towarzystwo Informatyczne, Warszawa, 55-94.

Lesiński J., Kociatkiewicz P. (2017), Komputer Odra 1103 [in:] Noga M., Nowak J.S. (eds.), Polska Informatyka: wizje i trudne poczatki, Polskie Towarzystwo Informatyczne, Warszawa, 277-280.

Maćkowiak B., Myszkier A., Safader B. (2017), Polskie komputery rodzity się w ELWRO we Wroctawiu. Rola Wroctawskich Zakładów Elektronicznych ELWRO w rozwoju informatyki w Polsce, Trzaskowska G. (ed.), Archiwum Państwowe we Wrocławiu, Wrocław.

Madey J., Sysło M.M. (2000a), Początki informatyki w Polsce, cz. 1, Informatyka, 9, 14-19.

Madey J., Sysło M.M. (2000b), Początki informatyki w Polsce, cz. 2, Informatyka, 10, 18-21.

Miś B. (1974), Od Abaka do Eniaca, czyli jak człowiek nauczył maszyny liczyć, Krajowa Agencja Wydawnicza Warszawa.

Morawski W. (2011), Dzieje gospodarcze Polski, Warszawa.

Popiński K. (2017), Wroctawski Ośrodek Informatyczny w latach 1959-1989 [w:] Nowak J.S., Ostrowska B. (eds.), Polska Informatyka: systemy i zastosowania, Polskie Towarzystwo Informatyczne, Warszawa, 61-137.

Rutkiewicz I. (1966), Archipelag nauki, Ossolineum, Wrocław-Warszawa-Kraków.

Sysło M.M. (2000), Komputery w edukacji - wyjątki z historii, mmsyslo.pl/.../Historia_ komp_w_edukacji_PL_do_1994_MMSyslo.pdf, accessed 27.10.2020. 
Tempski Z. (1970), Przemyst [in:] Biełowicz W. (ed.), Dolny Ślaskw Polsce Ludowej, Ossolineum Warszawa-Wrocław-Kraków.

Wspomnienia mgr. inż. Witolda Podgórskiego (nd), www.elwrowcy.pl, accessed 27.10.2020.

Ziemkiewicz A., Jezierska-Ziemkiewicz E. (2017), Rodzina maszyn K-202/Mera-400/MX-16 [in:] Polska Informatyka: systemy i zastosowania, Polskie Towarzystwo Informatyczne, Warszawa, 112-113;

Zuber R. (nd), Moje wspomnienia z Elwro, www.elwrowcy.pl, accessed 27.10.2020.

Krzysztof Popiński, assistant professor at the Department of Philosophy and Economic History at the University of Economics in Wrocław; his research interests focus on the political, socio-economic and cultural history of Poland and Germany in the 19th and 20th centuries; including higher education, industry and everyday life of Silesian cities. 